\title{
Translating Community Needs into Architectural Design Programs: A Study of Australian Muslim Cultural Centers
}

\author{
Dr. Mona A. Omar
}

\begin{abstract}
Australia has a large number of Islamic organizations, schools and mosques yet, there is a significant shortage of Islamic community centers that provide socio-cultural and recreational services to the growing number of Australian Muslims. This is also associated with a lack of academic research into Islamic architecture in Australia. This paper aims to answer questions on the type of architectural design criteria and programs required to build a functional Muslim cultural center and the nature of Muslims' obligations and socio-cultural needs. This research paper hypothesizes that Muslim communities in the West would be better served if their mosques are designed as community centers that meet their socio-cultural needs and their religious obligations. The study also demonstrates the Islamic center's model that provides the necessary programs and helps facilitating a variety of educational, socio-cultural, economic and spiritual activities, which can fulfil Muslims' needs, and build on social cohesion, harmony and security with the broader Australian community. The outcomes are translated into an architectural program and conceptual proposal for a functional Muslim cultural center. The research findings can also assist architects and Muslim organizations in Australia, and in the West in general, to design and build an efficient and functional Islamic community center.
\end{abstract}

Keywords - Architectural design programs; Australian Muslim architecture; Socio-cultural centers, Community needs.

\section{INTRODUCTION}

Despite the large number of Islamic organizations, schools and mosques in Australia, there are a very few Islamic centers that provide socio-cultural and recreational activities to the growing number of Australian Muslims. This is also associated with a lack of academic research into Muslim built forms in Australia in particular, and in the West in general. This paper aims to answer questions on the type of architectural design criteria and programs required to build a functional Islamic community center, the kind and nature of Muslims' obligations, and to what extent Australian Muslim architecture fulfils these religious obligations and socio-cultural needs. To achieve these aims, the study intends to identify socio-cultural requirements, obligations and needs of the Australian Muslim communities.

The research conducts a study on the Muslim communities in Australia, focusing on Western Australia. This research

Manuscript received October 26, 2015.

Dr. Mona A. Omar is an Assistant Professor of Architecture at the College of Engineering, Prince Sultan University in Saudi Arabia, and a Fellow of the UK Higher Education Academy. paper hypothesizes that Muslim communities in the West would be better served if their mosques are designed as community centers that meet their socio-cultural needs, as well as their religious obligations. This paper intends to define the main architectural design criteria that constitute a functional Islamic center; such criteria can be translated into architectural proposals and design schemes. The proposed methodology is based on community focus groups and case-studies approach, whereby the author analyses and evaluates two Islamic centers in Australia to extract and define their main architectural design criteria.

The study demonstrates the Islamic center's model that provides the necessary programs and helps facilitating a variety of educational, socio-cultural, economic and spiritual activities, which can fulfil Muslims' needs, as well as build on social cohesion, harmony and security with the broader Australian community. The outcomes are translated into an architectural program and conceptual proposal for a functional Islamic center. The research finding can also assist architects and Muslim organizations in Australia (and in the West in general) to plan, design and build an efficient and functional Islamic community center.

\section{History OF MusLims In Australia}

The history of Muslims in Australia dates back to the sixteenth century when Macassars (fishermen from Indonesia) interacted with Aboriginal communities living in the northern parts of the Australian continent [1]. Later, Muslim Malay divers were employed in the pearling grounds off Western Australia and the Northern Territory. By the 1870s, Australian pearlers were actively recruiting Asian divers for the pearling industry, acknowledged as being of primary importance to Australia's emerging economy [2].

During the gold mining boom of the 1890s, camel drivers coming from Afghanistan and present Pakistan worked at Coolgardie, Kalgoorlie and coastal port towns such as Albany, Fremantle, Geraldton, and Port Hedland. They lived in "Ghan" camps or towns following their Islamic faith. These Muslims started planning the Perth Mosque in William Street, Northbridge, in 1895. Its foundation stone was laid in 1905 and the mosque was opened in 1906. The camel era ended with the advance of railways, improved roads and motor transport. In the 1920s the number of Afghans and Muslim migrants in general declined with the end of the camel transport industry and the restrictive effects of the White Australia immigration policy. After World War II and in the 1960s, the restrictive Australian immigration policy has eased, consequently, more 
Muslims started migrating to Australia. They comprised different ethnic groups, mainly Malays, Arabs, Turks, Yugoslavs, Indians, Pakistanis, Afghans, South Africans, Burmese and Bosnians [3].

\section{CONTEMPORARY Muslims In AUSTRALiA}

According to the Australian Census 2011 [4], there were 476,300 Muslims living in Australia, comprising 2.25\% of the total population. Western Australia had the third highest Muslim population ( $8 \%$ of Australian Muslims), after New South Wales (50\%) and Victoria (33\%). In 2011, there was 39,160 Muslims living in Western Australia and the number has been growing since. As in other Western liberal democracies, Muslims have gone through the process of establishing social structures and institutions that reflect their Islamic identity [5].

\section{A. Muslim architecture and built forms in Australia}

Australian Muslims have a wide range of organizations and built forms providing religious, educational and welfare services. In 2007, there were more than 100 mosques around Australia and over 50 musallah (prayer halls) catering for Muslims' religious obligations and needs; and the numbers of Islamic buildings and users are increasing [6]. There were also around 50 Islamic schools attended by 15,000 to 20,000 students [7]. Therefore and for the purposes of this research, Muslim Architecture can be defined as buildings that provide religious, educational and socio-cultural and recreational services to the Muslim communities, which includes mosques, musallahs, Islamic schools and colleges, as well as Muslim community centers [8].

\section{B. Muslims religious obligations}

This research focuses on Muslims' needs based on their Islamic obligations, because for them Islam is not only a religion, but also a complete way of life; in a balanced and moderate way. The Qur'an, together with the sayings and deeds of Prophet Muhammad, the 'hadith', set out the five fundamental practices for Muslims, which can be summarised as: the testimony of faith (a declaration of belief in one and only God and Mohammed as his last messenger); praying five times a day; fasting during the holy month of Ramadan; giving charity or alms; and finally pilgrimage to Mecca [9].

\section{RESEARCH METHODS}

To answer the research questions, the methodology uses a mixed methods approach [10], including focus groups, surveys and interviews [11], to highlight the Australian Muslims community needs, taking the West Australian Muslim community as an example. The research methods also include case studies analysis of two Muslim community centers to define their architectural programs and design criteria.

\section{A. Research hypothesis and approach}

This research paper hypothesizes that Islamic community centres can play a significant role in developing and improving the socio-cultural activities of Muslims in Australia, and in the
West in general. Australian Muslims' socio-cultural needs and requirements can be interpreted and translated into architectural programs, conceptual design schemes and proposals, which can be developed to produce functional and more efficient Islamic community centres. The framework for analysing and assessing such centres is based on fulfilling all or most of the services and facilities that meet Muslims' socio-cultural needs.

\section{B. Research techniques and data collection}

In order to achieve the research objective (to define the appropriate architectural design criteria of a functional Islamic center s), and to answer questions on the kind and nature of Muslims' obligations and to what extent Australian Muslim architecture fulfils their socio-cultural needs, the research methods have been designed to:

- Conduct group interviews 'Focus Groups' and surveys to assess the socio-cultural challenges that contemporary West Australian Muslims face in Perth today and to identify their needs and requirements,

- Recognize the role of the socio-cultural Islamic centers in promoting mutual understanding and harmony between all Australians irrespective of faith, caste, creed or color,

- Select, study and analyses two case studies from Australia to identify their main architectural design criteria, which can be generalized to define a functional Islamic community center.

\section{A STUdy On THE WeSt AUSTRALIAN MUSLIM COMMUNITY AND ITS NEEDS}

The main research question "What are the architectural design criteria and programs required to build a functional Islamic community center that can fulfil Australian Muslims' socio-cultural needs?"

This study also aims to answer the research secondary questions: "What are the Muslims' obligations and needs?" and "To what extent Australian Muslim architecture fulfils its community's religious obligations and socio-cultural needs?" These questions are a manifestation of the research motivation to address "the lack of academic research into the types or variety of contemporary Muslim built forms in Australia, particularly in Western Australia and the need for Islamic community centers that provide socio-cultural and recreational services to the growing number of Australian Muslims".

To define the socio-cultural needs of the West Australian Muslims, qualitative group interviews/focus groups have been conducted with community members. The data collection has embraced as a diverse range of views as possible, including respondents of different ethnicities, age groups and economic backgrounds.

The topics covered in these focus groups have included the following:

- The most common ways of Muslims getting together in Western Australia,

- The ways of preserving their Islamic identities in WA,

- The significance of Islamic institutions to Muslims in WA, 
- The variety of services that mosques and Islamic centers can provide to the Muslim communities,

- The socio-cultural needs of Muslim communities in Western Australia,

- The main challenges that Muslims face in Australia,

- The importance of Islamic centers in developing and integrating West Australian Muslims into the larger community of Australia,

- The most important activities that Muslims should have in an Islamic center.

\section{A. The Focus Groups data analysis and interpretation}

Interpretation of the focus groups analysis has found that majority of the Muslim participants $(86 \%)$ believe that Islamic institutions in Western Australia are very significant for their potential to provide numerous cultural and entertaining services that are currently not available, such as female-only swimming facilities and free Islamic environment for women wearing hijab as well as venues for special Muslim celebrations (marriage, parties, etc.). Islamic institutions would also enable Muslims to fulfil their spiritual and social needs. They would help them to keep connected and informed of special events and news that concern Muslims. They would also help Muslims preserve their identities and they would provide support and assistance to the West Australian Muslim community.

Moreover, Islamic institutions can provide venues to invite non-Muslims and initiate events that help Muslims to integrate with the wider community. Concerning socio-cultural needs of the Muslim community in Western Australia, the participants find that 'Muslims gathering' comes as their top priority, 'learning Islamic values' comes as second priority, 'socializing with non-Muslims' comes as third priority, 'fitness and sports' comes as fourth priority, 'learning Arabic language' comes as fifth priority, 'learning Australian culture' comes as sixth priority, and finally 'learning English language' comes as seventh priority'.

The above socio-cultural needs would give architects and Muslim organizations leaders some guidelines and directions as to the design requirements of a mosque or an Islamic community center. The following architectural requirements have been deduced from the Focus Group responses.

A Socio-cultural Islamic center should provide the following:

- Adequate spaces for Muslims gathering, such as large multipurpose halls that could accommodate social and cultural activities and should be inviting to non-Muslims as well.

- Fitness and sports spaces and facilities such as gymnasium (for both genders), indoor swimming pool as well as indoor and outdoor activities.

- Sufficient lectures halls and classrooms that could accommodate cultural seminars, workshops and classes for teaching Arabic and English languages as well as Islamic culture.

\section{B. Outcomes of the Focus Groups analysis}

The research has found that the Muslim community in Western Australia face some challenges such as lack of understanding from the wider community to who Muslims really are and what they believe in. In this context, the respondents indicated that the media has a significant influence on how Australians perceive Muslims. Some respondents feel that they are not accepted by non-Muslim Australians. Other participants find it hard to: preserve their Islamic culture, raise their Muslim children in a Western society and change the negative image and sentiments towards Muslims. Other challenges are summarized as: Muslims' feeling of being excluded, pressure on Muslims to prove themselves within workplaces and other institutions, underlying discrimination against Muslim minority, lack of sense of belonging and finally the absence of strong and positive Muslim leadership.

These challenges reflect the feeling of insecurity of the Muslim communities as a minority in non-Muslim environments. The previously mentioned needs and challenges could be dealt with through a socio-cultural Islamic community center. Such center would make a suitable medium that bring Muslims and non-Muslims together, which can help bridging the gaps and bring tolerance and harmony in multi-faiths and multicultural society such as Australia. It would provide a positive environment for dialogues and social interactions during open days, seminars and workshops, which would create a feeling of inclusion and security to both parties. It would also provide the Muslim communities a seemly place for social gathering on social and religious occasions, classes and seminars, which would give them a sense of unity and belonging.

In respect to activities provided by mosques or Islamic centers in Perth, the participants have indicated that the majority of the centers provide religious activities but much less active in socio-cultural and recreational activities. This underlines the need for more Islamic socio-cultural centers to fulfil the growing needs of the Muslim community in Western Australia and tackle the lack in social, cultural and recreational services available for West Australian Muslims, especially for women and youth. Regarding to the importance of socio-cultural Islamic centers to Muslims in Western Australia and their role in developing and integrating them, the majority of the Focus Groups participants find that Islamic centers are very important in developing and integrating West Australian Muslims (76\%), while the rest of the respondents find them just important. The participants also find that the most important roles of socio-cultural Islamic centers in developing and integrating West Australian Muslims are (in order): promoting harmony between Muslims and non-Muslims, promoting harmony between Muslims from different backgrounds, and finally helping Muslims to adapt to Australian society and promoting good citizenship.

The analysis has also found that the top facilities needed in an Islamic center for the West Australian Muslims are in the order of a prayer hall, a recreation multipurpose hall, a library, teaching classrooms, a gymnasium, a conference room, a playground, a restaurant, a bookshop and finally a Muslim clothing shop. In relation to availability and adequacy of socio-cultural activities, the majority of the participants $(80 \%)$ indicated conspicuously that Islamic centers in Western 
Australia do not provide adequate socio-cultural services.

\section{CASE STUDies ANALYSIS}

The following sections demonstrate and analyze two case studies of Australian Muslim community centers, in order to define the Islamic center's model that can provide the necessary programs and helps facilitating a variety of educational, socio-cultural, economic and spiritual activities, which can fulfil Muslims' needs, and build on social cohesion and harmony with the broader Australian community.

\section{A. Case study 1: The Swan Valley Bosnian Mosque and Islamic Centre}

\section{- Community needs}

The number of the Bosnian Islamic Society members in Perth has increased enormously since its establishment in 1996. However, it did not have a place for its members to practice their religious obligations, such as daily prayers and Islamic classes nor its own office. Consequently, it was unable to employ a permanent Muslim leader and its members had to perform their daily prayers in different mosques. In 2006, the society bought a large block of land to build its own mosque and Islamic center. The land was purchased with funds collected from the society members [12].

\section{- Design criteria and process}

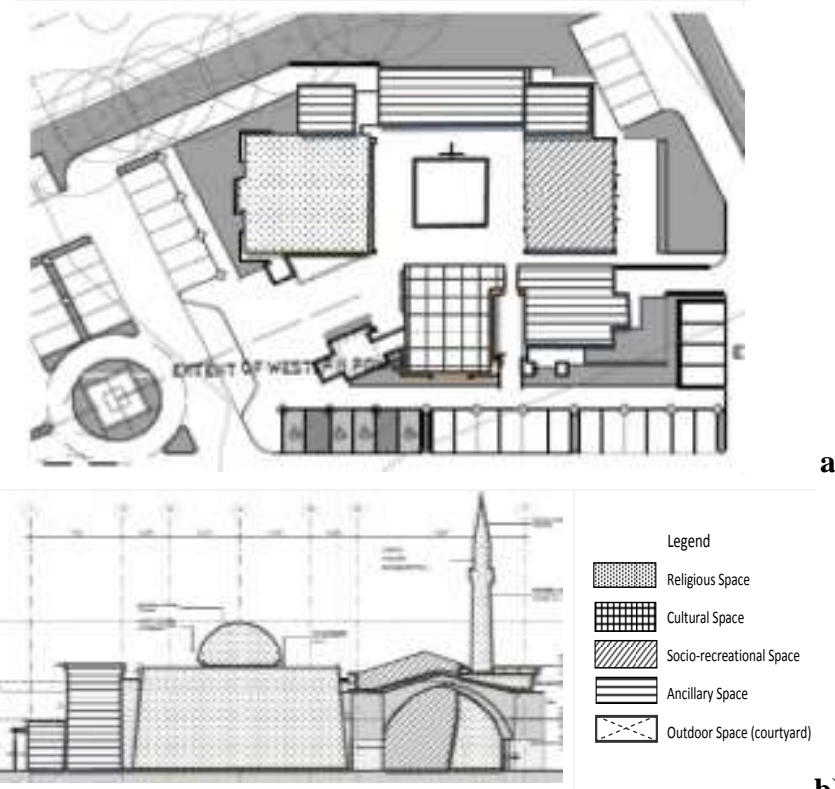

b)

Fig. 1: The Sawn Valley Islamic Centre, a) site plan and b) Elevation analysis. (Source: the author)

The Bosnian Society needed to build their own Islamic center that includes a mosque and a variety of socio-cultural activities, funeral services and religious teaching services along with the provision of the caretakers and short term residences. The total area of the project land is $9,405 \mathrm{~m} 2$ of which an approximate built-up area of $1,356 \mathrm{~m} 2$ is used. The complex consists of a mosque and an Islamic center, which include a prayer hall that can accommodate 350 worshippers; a multipurpose hall for a variety of socio-cultural activities such as weddings, funeral services and religious teaching services; a preparation area; a large kitchen ablution and toilet facilities; a caretaker's residence and 3 short term residences. The center also provides onsite car parking area of 83 car bays for its members and visitors (Figure 1).

\section{- Function}

The Bosnian Islamic Centre's design provides religious, social, cultural and recreational services to meet the needs of the growing Muslim community in Swan Valley and surrounding areas. The Centre offers a wide range of activities such as a large mosque for male and female prayers, Islamic classes Madrasah for children and adults, a large library for Islamic books in English, Arabic and Bosnian languages, and a multipurpose hall for social, cultural and recreational activities. The center also provides ancillary activities such as ablution, showers and toilet facilities to serve worshipers and other users as well as a residence for the mosque leader Imam, 3 short term accommodations and an admin office (Figure 2).

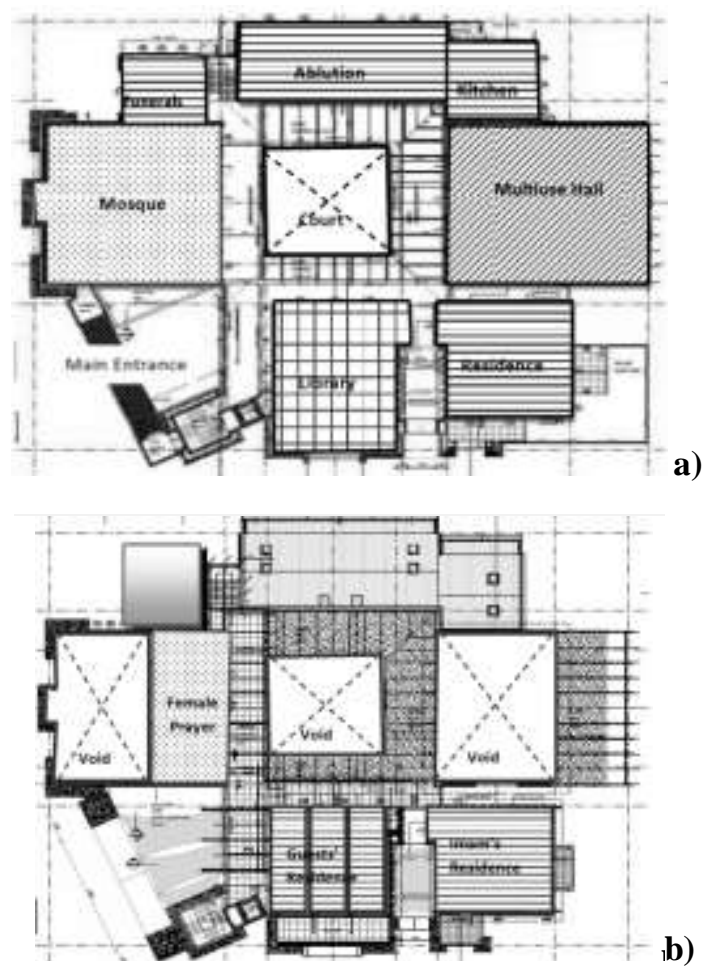

Fig. 2: The Sawn Valley Islamic Centre, a) Ground and b) First floor plans analysis. (Source: the author)

\section{B. Case Study 2: The Newport Islamic Centre \\ - Community needs}

The Newport Islamic Centre, in Melbourne, provides a place of worship to the Muslim community in Hobsons Bay and accommodates their religious needs. The old facility (prior to building the new center) at the corner of Mason Street and Walker Street ran out of capacity and was over congested, as worshipers had to pray in the car park and in the street on numerous occasions.

\section{- Design criteria and process}

The Newport Islamic Centre is a comprehensive complex 
with spiritual, educational and recreational facilities. It is built in three stages, each stage consisting of a number of buildings and areas. The complex includes a mosque for both male and female worshippers; an educational center consists of a library, eight class rooms for Arabic and Islamic studies, and two quite reading rooms; an indoor recreational and functions center; a residence for the mosque leader and 2 guest houses. The site includes a parking for about 180 cars, in addition to the public car park developed by the council in front of the center.

\section{- Function}

The design of the Newport Mosque provides sufficient indoor prayer space for the five daily prayers, as well as for important days of the Islamic calendar such as Friday and festive 'Eid' prayers. The new spacious Islamic center accommodates the spiritual, socio-cultural and recreational needs of the large Muslim community in Hobsons Bay and its surrounding areas. Its indoor environment meets community and safety standards in Australia as well [13]. The education center provides an important venue for learning Arabic language and Islamic knowledge for all society members in Hobsons Bay and the rest of Melbourne. Social facilities accommodate for social needs of various streams and ages of the Muslim and local communities (Figure 3).
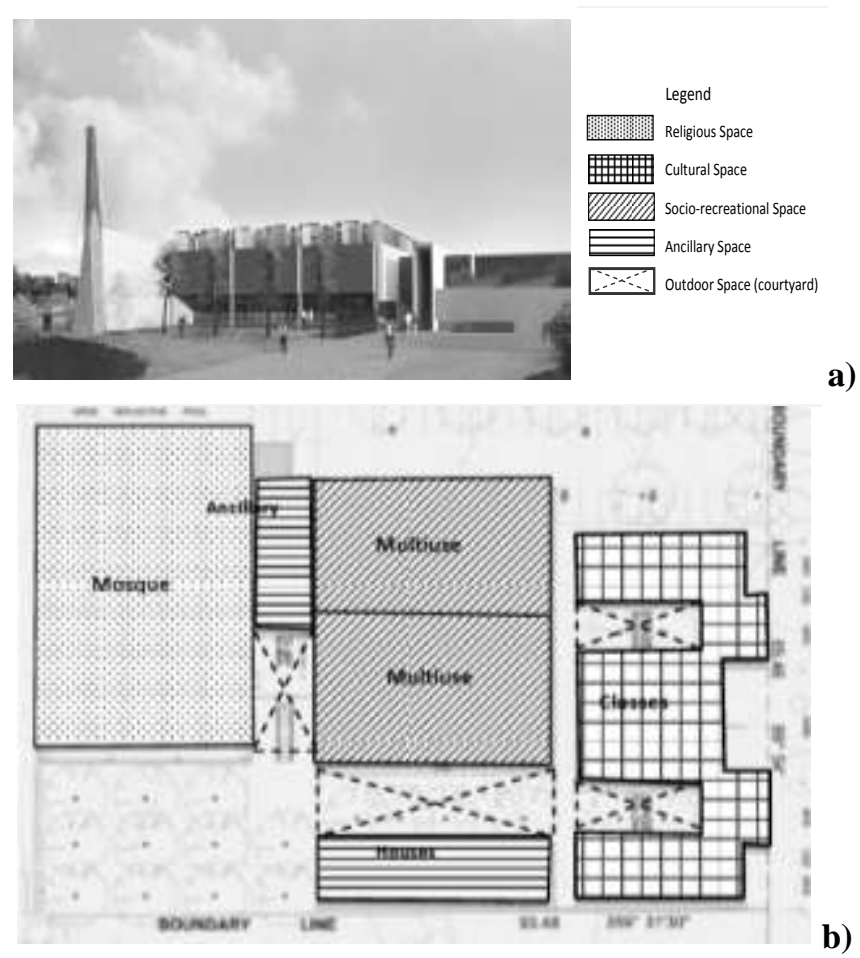

Fig. 3: Newport Mosque's, a) Front view and b) Analysis (Source: the author)

\section{THE RESEARCH OUTCOMES}

In concluding this paper, analysis of the research case studies has indicated that in both case studies, the mosque complex or Islamic center serves as a community center.

The case studies design elements are controlled by requirements for religious spaces, cultural and educational spaces, social spaces and recreational spaces. The importance and availability of the ancillary spaces depends on the needs of each case study and varies from case to case.

\section{A. Criteria of a functional Islamic centre}

The study finds that a functional Islamic centre should include and fulfil all social and cultural needs for a modern community within Islamic frameworks that do not contradict with Islamic teachings in principles. These needs include, but not limited to, the following:

a. Social needs (to create a balance between Islamic principles or obligations and modern Western lifestyle). Social activities include community gathering and networking; marriage and birth celebrations; festive celebrations; Ramadan dinners Iftaar and Islamic gathering; halal food catering; crèche/childcare facilities; women, youth and seniors' activities, family counselling, welfare and funeral facilities.

b. Cultural needs (to enrich the minds and strengthen the knowledge). Cultural activities include Islamic library and resource centre; art and cultural exhibitions; weekend and holidays Islamic classes; English/Arabic classes; interpreting and translation services; sports and recreation services; media representation; seminars and guest speakers; multicultural activities; open days with the wider non-Muslim community, interfaith dialogues.

c. Spiritual needs (to create a balance between spiritual and materialistic lifestyle). Spiritual activities include daily collective prayers, weekly Friday prayers, festive Eid prayers (twice a year) and Ramadan late night prayers (one month a year) as well as learning Islamic practices and Quran recitation.

More importantly, the study has answered the research question as 'What are the architectural design criteria required to build an Islamic community centre which can fulfil Australian Muslims' socio-cultural needs, promote their development and provide a closer relationship with their fellow non-Muslim citizens?'

This study has provided an investigation and analysis for the selected Islamic centres as case studies from Australia. It has delivered interpretations for the case studies results and defined their main architectural components and design elements. The outcomes of the analysis are useful as guidelines for developing the author's proposed architectural program and conceptual scheme, which will be demonstrated later in this paper.

The following section demonstrates the author's proposed architectural program and conceptual design scheme of a socio-cultural Islamic centre's model to serve Muslim communities in the West; based on the research findings and outcomes.

\section{B. Architectural program and conceptual proposal for a functional Islamic centre}

Muslims' needs and requirements include spiritual, social, cultural and recreational aspects. These needs and requirements can be translated into zones and spaces to form an architectural program and conceptual design scheme for a functional Islamic centre in the manner depicted below (Figure 4): 


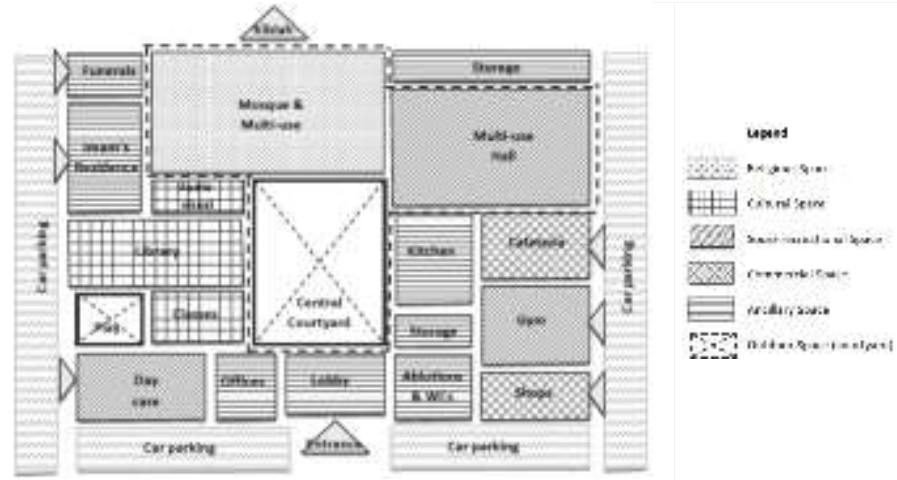

Fig. 4: Conceptual proposal for a functional Islamic centre (Source: the author)

- Social spaces include: a large multipurpose hall and its services such as a storage room and a large kitchen, which could host community gathering and networking; marriage and birth celebrations; festive celebrations; Ramadan dinners Iftaar and Islamic gathering; halal food catering; women, youth and seniors' activities, family counselling, and childcare facilities.

- Cultural spaces include: an Islamic library and resource centre; art and cultural exhibitions; weekend and holidays Islamic classes; English/Arabic classes; interpreting and translation services; media representation; seminars and guest speakers; multicultural activities; open days with the wider non-Muslim community and interfaith dialogues.

- Spiritual/religious spaces include: a main prayer hall; a funeral room and services such as a storage room; ablutions and toilets facilities. The main prayer hall hosts the five daily prayers, Friday congregation prayers and the festive large scale prayers (twice a year) and Ramadan late night prayers (one month a year), as well as learning Islamic practices and Quran recitation, welfare and funeral events.

- Sports and recreation spaces include: a gymnasium; a children playground and outdoor sports.

- Commercial spaces to generate financial income and self-sufficiency, and to ensure ongoing centre's operation; they include a cafeteria and shops to sell halal food, books and closing.

- The architectural program for a functional Islamic centre should also include an accommodation for the mosque's leader; the Imam and his family. In addition to a sufficient onsite car parking.

\section{CONCLUSIONS AND RECOMMENDATIONS}

The research has identified the socio-cultural requirements, obligations and needs of Australian Muslim communities. They can be summarized as religious obligations, educational, social, cultural needs. It has provided an understanding of the relationship between the socio-cultural needs of Muslim communities in the West and the architectural criteria that govern the Islamic center's design process. The research has also defined the main architectural design criteria for two Islamic centers in Australia and developed an architectural program for a purposeful Islamic center's model that would fulfil the socio-cultural, recreational and spiritual needs and requirements of the Muslim communities in the West. It can also provide social interaction, harmony and understanding between Muslim and non-Muslim Australians.

The research has found that mosques and Islamic centers design in the West tend to incorporate a wider range of socio-cultural and recreational activities. Therefore, the design and development of mosques in the West needs to include community focused multifunctional roles within the design response. It is also recommended that Islamic centers design in non-Islamic environment becomes modern and innovative rather than being classic imported built forms. A positive Islamic center's design should provide facilities to which all people could be invited to use and experience; these facilities include a multipurpose recreation and conference hall, indoor sports, open day events and weekend community markets.

The architects should create energetic and active place, and the center's management should initiate and organize the appropriate activities and functions around their project's facilities. Moreover, the architects need to make the building legible, accessible and inviting; this can be achieved by both ensuring that there are welcoming entry points and providing architectural forms that express the identity of the community whilst commemorating positive activities. The research has found that Islamic socio-cultural centers can offer a better understanding for Muslims' culture and way of life in a positive way. Moreover, they can help bridge the gap between Islamic and Western cultures.

\section{REFERENCES}

[1] Yasmeen, S. Understanding Muslim Identities: From Perceived Relative Exclusion to Inclusion. Centre for Muslim States and Societies. Perth: University of Western Australia, 2008.

[2] Matthews, Z. Muslims in Australia, 2007 [Online]. Available: http://www.aim.org.au/articles.asp?article $=63$

[3] Cleland, B. 2001. The History of Muslims in Australia. In Muslim Communities in Australia. Sydney: UNSW Press.

[4] Australian Bureau of Statistics ABS 2011 Census [Online]. Available: http://www.abs.gov.au/websitedbs/censushome.nsf/home/Data

[5] Australian Federation of Islamic Councils website (AFIC) [Online]. Available: http://www.afic.com.au

[6] Yasmeen, S. 2008. Understanding Muslim Identities: From Perceived Relative Exclusion to Inclusion. Centre for Muslim States and Societies. Perth: University of Western Australia.

[7] Matthews, Z. Muslims in Australia, 2007 [Online]. Available: http://www.aim.org.au/articles.asp?article $=63$

[8] Omar, M. 2010. Muslim Built Forms in Perth: Fulfilling [or Not] Community Socio-cultural Needs. Conference Proceedings, 11th Humanities Graduate Research Conference, 11-12 November. Perth: Curtin University.

[9] Aussie Muslims Network. Perth [Online]. Available: http://www.aussiemuslims.net

[10] Kumar, R. 2011. Research Methodology: a step-by-step guide for beginners. London: Thousand Oaks, California.

[11] Muir, J. 2011. DIY Focus Groups: Inside the Researchers Toolbox. Postgraduate Research and Development Workshop, Power point presentation handout. Perth: Curtin University [Online]. Available: http://www.australianislamiccentre.com.au/community

[12] Swan Valley Bosnian Mosque and Islamic Centre (SVBM \& IC) [Online]. Available: http://www.bosnianislamicsocietyperth.com.au

[13] Australian Islamic Centre AIC (The Newport Hosbons Bay Mosque and Community Centre), Melbourne [Online]. Available: http://www.australianislamiccentre.com.au/community 


\section{Author's Biography}

Dr. Mona Omar is an assistant professor of architecture at the College of Engineering at Prince Sultan University in Saudi Arabia. She is also a Fellow of the UK Higher Education Academy. Dr. Mona has over 25 years of combined experience in academic teaching, research and as a professional architect in Australia, Kuwait and Egypt. She has received her Doctoral and Master's degrees from Curtin University in Australia. She has also completed a Postgraduate Certificate in Higher Education Teaching and Learning. Dr.

Mona was granted the Australian Postgraduate Award and the Curtin University Research Scholarship, in recognition of her research significance. She has been recently awarded the Prince Sultan University research grant for her book authorship concerning environmental control and sustainable design. Dr. Mona's research interest and publications include Architecture and Culture, Islamic Architecture in Australia and the West, Green Architecture and Sustainable Built Environment. 